\title{
A MONTANHA MÁGICA ESCALADA POR WALTER BENJAMIN
}

THE MAGIC MONTAIN CLIMBED BY WALTER BENJAMIN

Eduardo Gusmão Quadros* eduardo.hgs@hotmail.com

RESUMO: Esse texto apresenta uma reflexão acerca das mudanças recentes ocorridas na experiência temporal e os desafios para interpretá-las nos quadros das Ciências Humanas. Tomamos como base o romance A Montanha Mágica, escrito por Thomas Mann, lido em diálogo com as ideias de Walter Benjamin acerca do tempo histórico. Defende-se que as críticas de ambos à modernidade capitalista fornecem pistas interessantes para a possível melhoria da sensação de asfixia que permeia o mundo contemporâneo.

PalAVRAS-CHAVE: Capitalismo, Tempo, Epistemologia.

ABSTRACT: This text presents a reflection on recent changes in temporal experience and the challenges to interpret them in framework of Human Sciences. We take the novel The Magic Mountain, written by Thomas Mann, as a base and read this work in dialogue with Walter Benjamin's ideas about historical time. It is argued that their criticism of capitalist modernity provides possible clues to curing the feeling of suffocation that permeates the contemporary world.

KEYWORDS: Capitalism, Time, Epistemology.

É sempre bom lembrar Que um copo vazio Está cheio de ar Gilberto Gil (1974)

Eu não consigo respirar! Esse foi o sufocado clamor, repetido várias vezes por George Floyd, homem negro assassinado em 25 de maio de 2020 pela polícia de Minneapolis (USA). Sua morte despertou protestos em várias partes do mundo, surgindo passeatas e denúncias contra o racismo estrutural que, ainda, caracteriza o mundo globalizado, não somente a sociedade norte-americana. Antes disso, em 2014, Eric Garner havia sido morto em Nova York em situação bem semelhante e com o mesmo aviso insistente: Eu não consigo respirar! Parece que esse grito coletivo é um topos para captar "o novo tempo do mundo", como denomina o filósofo Paulo Arantes (2014), esse "tempo da emergência", que também é sanitária. A atuação violentamente repressiva tem pretendido, de forma sistemática, impedir as camadas subalternas de aspirar a novos lugares sociais e políticos ${ }^{1}$.

\footnotetext{
* Doutorado em História pela Universidade de Brasília. É professor da Pós-graduação Pontifícia Universidade Católica de Goiás e da Pós-graduação da Universidade Estadual de Goiás (PROMEP).

${ }^{1}$ Essa relação entre a repressão policial, os controles biopolíticos e sufocamento dos subalternos, a partir dos assassinatos referidos, foi feita por Gabriel Apata (2020), ainda que o autor não aborde a questão da temporalidade. Uma síntese das informações acerca dos crimes e dos protestos que se seguiram pode ser lida na Wikipedia, tanto para George Floyd (https://pt.wikipedia.org/wiki/Assassinato de George Floyd,
} 
A pandemia de COVID - 19, que se espalhou pelo mundo tão rapidamente desde o início de 2020, causa uma síndrome respiratória aguda que leva à falta de oxigenação do organismo. O alto número de mortes e a velocidade do contágio praticamente parou o mundo, fechou as fronteiras dos países, levou a fome, ao desemprego e ao isolamento bilhões de pessoas.

Enquanto isso, o Fórum Econômico Mundial, que se reúne na cidade suíça de Davos todos os anos desde meados dos anos setenta, planeja forjar "o grande reinício" (The great reset). Em artigo publicado na revista Time, seu fundador e presidente executivo, Klaus Schwab, confirmou em meio às incertezas "sua crença que um sistema capitalista mais virtuoso é possível" e para isso "nós necessitamos reimaginar o capitalismo" (SCHWAB, 2020). O diagnóstico que traçamos nesse artigo para o tempo contemporâneo vai em direção oposta.

Assim, utilizamos como símbolo fulcral a reunião periódica desses milionários e líderes mundiais em Davos para realizar uma leitura econômico-política do romance $A$ Montanha Mágica, escrito por Thomas Mann na segunda década do século XX. Ele tem sido considerado uma obra literária que reflete acerca do tempo (Zeitroman)², mesmo que sua estória possua como cenário um sanatório para doenças respiratórias situado na cidade suíça referida. $\mathrm{O}$ arcabouço interpretativo advém das ideias de Walter Benjamin, que morreu enfrentando os fascismos ${ }^{3}$ e imaginou de forma radical um mundo além do regime capitalista.

\section{O anacronismo: uma via metodológica}

O termo anacronismo em textos de história costuma causar arrepios. Acostumamos na pesquisa a seguir o famoso conselho de Lucien Febvre de que se deve "evitar o pecado dos pecados, o pecado entre todos irremissível: o anacronismo" (apud DUMOULIN, 1993, p.47). $E$, em seu verbete, Dumoulin comenta o caso de outro francês importante na formação do método histórico, Charles Victor Langlois, que recusara a interpretar os documentos, pelo medo de cair impiedosamente em tal "pecado" (DUMOULIN, 1993, p.48).

\footnotetext{
consultada em 06/02/2021) quanto para Eric Garner (https://pt.wikipedia.org/wiki/Morte de Eric Garner, consultada em 07/02/2021).

${ }^{2}$ O próprio Thomas Mann classificou-o dessa forma quando comentou seu livro, em 1939, para os estudantes da Universidade de Princeton (MANN, 1996, p.138).

${ }^{3}$ Um esboço dessa interpretação da obra de Mann foi apresentada na live promovida pelo GT de Teoria e História da Historiografia da ANPUH, em 07/10/2020, para relembrar os oitenta anos da morte de Benjamin nesse combate. Disponível em: https://www.facebook.com/ANPUH/videos/795664571188584.
} 
Tal regra possui seu valor, mas tem sido questionada em diversos casos. Um dos historiadores que propôs radicalmente o anacronismo enquanto elemento essencial da pesquisa histórica foi o, também francês, Georges Didi-Huberman. Para ele, não faz sentido essa atitude canônica de rejeição promovida pela comunidade historiadora, pois a imagem em si apresenta "uma extraordinária montagem de tempos heterogêneos, formando anacronismos" (2015, p. 23). Portanto, explorar um método anacrônico se faz tão necessário quanto fecundo (2015, p. 25) e deveria ser assumido com coragem o fato de que "toda história é anacrônica" (2015, p. 48).

Didi-Huberman trabalha estudando imagens e gravuras, com a área da história da arte. Isso é importante para nossa abordagem nesse texto, pois ele tem refletido sobre as possibilidades simbólicas da figuração. Propomos, aqui, realizar uma leitura assumidamente figurativa da obra de Mann, explorando suas possibilidades alegóricas. Isso, seria, sugere o autor francês (DIDI-HUBERMAN, 2015, p. 101), produzir exatamente uma "história a contrapelo", como provocava Benjamim nas suas Teses sobre o conceito de História (BENJAMIN, 1994, p. 225).

Então, de maneira proposital, iremos argumentar na direção oposta ao trabalho exaustivo que fez o colega Pedro S. P. Caldas (2014), quando contextualiza Thomas Mann e sua obra, chegando a encontrar nos personagens d’A Montanha Mágica reflexos de personagens históricos. Não que discordemos da tese central do artigo, que considera o livro um "romance de formação", mas, por isso mesmo, valorizando os "propósitos político pedagógicos" da obra (2014, p. 109), vamos transcender o momento de sua elaboração para aplica-la alegoricamente aos dramas do presente.

Isso seria uma simples manipulação? Ou um uso indevido da literatura pela história? Não pensamos assim. Até porque, conforme o próprio Mann, ele utilizara na redação uma linguagem hermética, eivada de hieróglifos, com influência, até, da alquimia (MANN, 1996, p. 140). Se o livro pode ser considerado um romance realista, a narrativa "sempre ultrapassa o real, elevando-o simbolicamente", afirma (1996, p. 139).

A utilização abundante dos hieróglifos e das alegorias é comum em épocas de tragédia, sustentava Benjamin (1984, p. 184). De forma coincidente - uma stimmung, como se diz em alemão - os dois pensadores ressaltaram essa capacidade abstrativa da linguagem 
nos primeiros anos da década de vinte do século passado 4 . 0 drama vivido na Primeira Grande Guerra levou-os a essa maior sensibilidade com a "história mundial do sofrimento" e despertou-os para a função da alegoria, instrumento privilegiado que "mostra ao observador a facies hipocrática da História" (BENJAMIN, 1984, p. 188).

Os tropos linguísticos já foram incorporados na epistemologia histórica, em particular após o abalo sísmico gerado pelas ideias de Hayden White na década de setenta. Suas ideias contribuíram para dirimir as ilusões com o solo historiográfico do realismo e do empirismo, além de demonstrar a íntima relação entre a forma narrativa, manifesta nos textos, com as opções políticas, geralmente não manifestas, dos autores. Entretanto, o padrão figurativo da realidade permaneceu como modelo de explicação da historiografia, mesmo nas obras de White (cf. DORAN, 2013, p. 22).

Pressupondo que o passado desafia-nos a interpretá-lo, hoje e sempre (DORAN, 2013, p. 33), exploraremos A Montanha Mágica buscando outras ferramentas, não contextuais, ainda que fixadas nas fendas erodidas pelo tempo. Vamos seguir a sugestão dada no prefácio da obra, de que a história não retira seu valor exatamente da distância cronológica, mas, ao inverso, da sua proximidade com o presente (MANN, 2009, p. 4). Essa "dialética" dos tempos provoca "a estrutura de um despertar", como ensinou Benjamin 5 .

\section{Do tribunal ao hospital}

A face hipocrática da história se revela. Na verdade, conforme a visão da medicina, a saúde seria um caso extremamente raro $^{6}$. A missão do saber médico é encontrar a doença que impediria os seres humanos de se realizarem. Para isso, como demonstrou Carlo Ginzburg, os médicos aprendem a decifrar os signos, a identificar os sintomas (semeion). "Apenas observando atentamente e registrando com extrema minúcia todos os sintomas -

\footnotetext{
${ }^{4}$ Mann publicou o livro em tela no ano de 1924 e Benjamin teve seu trabalho acadêmico submetido à banca em 1925, sendo redigidos, portanto, em época próxima. A ideia de que o período da Primeira Grande Guerra criou uma grande mudança na forma de perceber o tempo, o que formou essa stimmung, é descrita com riqueza de fontes no estudo de Stephen Kern (2003).

${ }^{5}$ Ele escreveu que: "Até agora se tomava o passado como um ponto fixo e se pensava que o presente tinha que esforçar-se para que o conhecimento se encontrasse com esse sólido ponto de referência. Agora, contudo, essa relação deve mudar no sentido de que o passado se converta em marco dialético, em acontecimento da consciência desperta. A política ostenta o primado sobre a história. [...] Existe um não saber consciente do passado cuja exigência tem a estrutura de um despertar (apud MATE, 1993, p.271). A afirmação benjaminiana do primado da política nos é importante e retornaremos a ela ao final do texto.

${ }^{6} \mathrm{~A}$ assertiva foi feita no primeiro encontro do personagem central do romance de Mann, Hans Castorp, com o médico diretor do sanatório (1991, p.16).
} 
afirmavam os hipocráticos - é possível elaborar 'histórias' precisas de cada doença". Importante ressaltar que, tal qual o passado, nesse registro gnosiológico, "a doença é, em si, inatingível" (GINZBURG, 1989, p. 155).

Essa forma de conceber a realidade contribuiu para o estabelecimento do método histórico, ainda na Grécia clássica. A outra vertente proveio do ambiente jurídico. Daí o papel fundamental que a testemunha assumiu. François Hartog descreve a função do histor nas disputas, daquele que possui condições de narrar com justiça e veracidade. Mais tarde, com o impacto do cristianismo, ganhou relevo o termo martus, que acrescenta a importante qualidade de guardar na memória. A principal diferença entre os termos ocorreria na articulação temporal, pois "o martus intervém no presente e para o futuro, enquanto o histor deve acrescentar a dimensão do passado" (2011, p. 213).

$\mathrm{Na}$ antiga Grécia, ouvir era o elemento principal do relato verdadeiro enquanto no meio romano cristianizado os fatos eram estabelecidos pelos que viram. Mais que isso até, pois os mártires deram testemunho da verdade, muitas vezes, com seu próprio sangue. A reunião de testemunhos poderia gerar certeza, como está escrito no prólogo do Evangelho de Lucas (1, 1-4). O tempo não mais era diferenciado, reunindo-se passado e futuro, ou, melhor ainda, colocando-se o passado a serviço do futuro.

No século XIX, a história foi incorporada na Universidade como uma ciência, a "ciência do passado", trazendo da linguagem judicial a autenticidade dos documentos, dos vestígios e dos testemunhos (HARTOG, 2011, p. 222). Essas são as fontes de conhecimento de onde a área extrai a verdade do que aconteceu. Mas existe outra dimensão dos julgamentos que o pesquisador não explorou, pois ele está preocupado prioritariamente com a historiografia acadêmica francesa. Trata-se de considerar o processo histórico em si como um grande tribunal, o que era bem mais evidente no historicismo alemão.

"A história do mundo é o tribunal do mundo", escrevera Hegel, e, analisado tal afirmação de aspecto dogmático, Karl Löwith percebia a secularização de um tempo messiânico, ou seja, o presente identificado com o processo de consumação do Reino de Deus (1991, p.64). Portanto, além do progressismo típico da filosofia da história no século XIX, há ali uma abertura para certo presentismo, ainda que nascente. Ao refletir sobre o plano imanente da história, o pensador aplicado "não a conhecia como profeta que prevê a 
catástrofe futura, mas como profeta ao inverso, estudando e justificando os caminhos do Espírito através dos seus sucessivos êxitos" (1991, p. 65).

As catástrofes chegaram, mas não o apocalipse. A teodiceia civil que vê os males como tropeços necessários, a exemplo da hegeliana, se tornou inviável após os massacres das grandes guerras. É possível ler a obra de Thomas Mann (2009) enquanto um exemplo desse tempo de espera que não possui esperança. No Sanatório Internacional de Berghof, local onde os personagens se encontram, não há cura e, como no processo natural da vida, todos buscam apenas postergar o momento da morte. Os problemas respiratórios os levam a subir a montanha, a buscar ar puro e conforto, contudo o oxigênio rarefeito está tanto no "alto", quanto na "planície".

Se Lukács estiver correto, o grupo do alto representa a postura da burguesia germânica. A obra traz uma reflexão acerca da falta de sentido no capitalismo, ao rumar para a morte da civilização (1964, p.35). A Grande Guerra foi apenas um episódio, por mais importante que tenha sido, mas depois de seu final consagrado, o processo suicida geral perdurou. A história passou a ser vista, portanto, sob a perspectiva da crise, ressaltando-se que esse termo é caracteristicamente hipocrático. Da distinção teológica entre salvos e condenados, passou-se à percepção de que todos estão, de algum modo, adoentados.

\section{Um espaço amoral}

Não há, evidentemente, grande novidade nesse diagnóstico. Reinhart Koselleck (2009) havia localizado a patogênese do mundo burguês - sua pesquisa foi feita na década de cinquenta - nos primórdios da modernização capitalista. A sensação de se viver em eterna crise tornou-se a maneira primordial de experimentarmos o tempo histórico. Outra importante ideia dessa obra recebeu, entretanto, menor atenção: a de que a noção moral foi alienada da realidade política na formação das democracias (KOSELLECK, 2009, p. 16 e 129).

A noção da história enquanto registro do progresso da humanidade, obviamente, possui uma visão moralizante. Quando Benjamin propôs a crítica implacável da ideologia do tempo progressivo na Tese XIII do conceito de história, estava tratando justamente da teoria social democrata" (BENJAMIN, 1994, p. 229). Por detrás da barbárie da cultura burguesa, estava a profunda indiferença com a vida e com a morte daqueles que trabalham na "planície", ou seja, as classes sociais inferiores. A indiferença acachapa a experiência significativa, 
fazendo a história perpassar por "um tempo vazio e homogêneo", como concluía a mesma Tese XIII.

De forma irônica, o personagem que encarna o humanista liberal no romance de Mann, o italiano Lodovico Settembrini, está redigindo verbetes para uma "Sociologia dos Males", a ser publicada em vinte volumes! A missão foi-lhe conferida pela Liga para a Organização do Progresso, consciente da "sua tarefa de promover a felicidade dos homens", de "lutar contra o sofrimento humano por meio de um adequado trabalho social e com o fim de exterminá-lo por completo" (MANN, 2009, p. 207). Ao apresentar o conteúdo desse grande tratado enciclopédico de "patologia sociológica", ele propagandeia:

Serão enumerados e tratados todos os males imagináveis dos homens, desde os males mais pessoais e mais íntimos até os grandes conflitos coletivos, os males que têm a sua origem nas inimizades de classes e nos entrechoques internacionais; numa palavra, a obra mostrará os elementos químicos que, em múltipla mistura e combinação, compõem todos os sofrimentos humanos, e, tomando por diretriz a dignidade e a felicidade dos homens, indicará para cada caso os remédios e as medidas que lhe parecem apropriados para eliminar a causa do mal (MANN, 2009, p. 207).

Obviamente, a pesquisa que realizava nunca será concluída. Faltaria tempo ou espaço para redigi-la? Obviamente, ambos. Uma das ideias centrais do romance, como aponta a análise feita por Paul Ricoeur, é a indissociabilidade entre espaço e tempo ${ }^{7}$. Desde o início da narrativa, ao subir a montanha, o engenheiro Hans Castorp anuncia que a mudança topográfica faz romper com a temporalidade normal, cronológica, adentrando em uma duração capaz de "transformar, em um só golpe, um pedante ou um burguesinho numa espécie de vagabundo". Tal estado de liberdade, como é interpretado pelo personagem, alcança-se por meio do desligamento das relações sociais e pelo esquecimento (MANN, 2009, p. 6).

Nesse sentido, podemos acrescentar à tese de Koselleck que ocorreu também a alienação da economia em relação à moral. $\mathrm{O}$ isolamento espacial em Davos relaciona-se com o isolamento social e com a suspensão dos marcos temporais entre o instante e a eternidade.

\footnotetext{
${ }^{7}$ Fazendo uma síntese da mensagem do livro, o filósofo francês afirma: "A princípio, a abolição do sentido de medida do tempo é o traço maior da maneira de existir e de morar dos pensionários do Berghof, o sanatório em Davos. Do início ao final do romance, este apagamento do tempo cronológico é claramente sublinhado pelo contraste entre "aqueles do alto", aclimatados nesse fora do tempo ("hors-temps") e "aqueles de baixo" - os da planície - que vivem ao ritmo do calendário e dos relógios. A oposição espacial marca e reforça a oposição temporal" (1984, p.168).
} 
Hegemonia da mesmice é igual a "tempo vazio e homogêneo". Cruzam-se, na narrativa do romance, o processo de suspenção temporal e a dessolidarização com o outro. Nesse ínterim, a crítica antifascista de Benjamin, que proclamava a necessidade de "fazer explodir o continuum da história" (Tese XV) e substituí-lo por "um tempo saturado de agoras" (Tese XIV), encontra-se com a crítica econômico-política de Tomas Mann.

O tempo da repetição é o da produção capitalista, da reprodução cultural voltada para o consumo. Revendo a noção da temporalidade do trabalho na teoria marxista, Hardt e Negri observam que:

O trabalho efetivamente continua a ser a fonte essencial de valor na produção capitalista, isto não muda, mas precisamos investigar de que tipo de trabalho estamos tratando e quais são as suas temporalidades. [...] Os ritmos regulares da produção fabril e suas divisões estanques entre o tempo de trabalho e o tempo em que não se trabalha tendem a declinar no reino do trabalho imaterial. [..] O novo paradigma solapa a divisão entre tempo de trabalho e tempo de vida (HARDT, M. e NEGRI, A., 2012, p. 193-194).

Isso significa que a lógica da mercadoria abarcou o que seria, na época de Marx, o tempo livre do lazer. Quem ganhou a batalha foi o tempo do cansaço. Mas não seria preciso parar, de vez em quando, para retomar o fôlego?

\section{Um horizonte diminuto}

Junto com a angústia da repetição está a da inação. Eis o problema. A urgência, essa temporalidade típica do trabalho atual pós-fordista, impele ao acúmulo de novidades em série, portanto não tão inovadoras assim. Benjamin não apontava para o intenso processo de empobrecimento da experiência no mundo tecnológico ${ }^{8}$ Como comenta Paolo Virno, a desorientação existencial serve para manter a superficialidade e a infantilização necessárias ao fluxo neoliberal da reprodução:

Tanto a criança como o habitante das metrópoles encontram-se sem tradições nem bússolas. Privados do abrigo de um "hábito", ambos confiam na repetição, a fim de se proteger dos choques do imprevisto e se orientar. [...] A experiência adulta permanece repetitiva, não alcança o hábito. Benjamin menciona até uma 'pobreza da experiência' geral que induz a 'recomeçar do início; a começar do novo; a contentar-se com o pouco'. [...] À repetição lúdica, a reprodutibilidade técnica opõe uma coação a repetir da

\footnotetext{
${ }^{8}$ Referimo-nos ao ensaio Experiência e Pobreza, onde ele defende que "as ações da experiência estão em baixa, e isso numa geração que entre 1914 e 1918 viveu uma das mais terríveis experiências da história" (BENJAMIN, 1994, p.109)
} 
mercadoria e do trabalho assalariado. A indústria cultural enfeita a 'pobreza de experiência' para que passe desapercebida... (2008, p. 89-90).

Sem alteridade, o próprio tempo histórico se esvai. Destarte, o alargamento do presente na cultura contemporânea, mapeado por Gumbrecht, não deve ser concebido como a frutificação de novos espaços, mas sua crescente escassez. O futuro e o passado se tornam cada vez mais semelhantes, ainda que continuemos a falar de história, de mudanças ou de novas perspectivas. "Entre os passados que nos engolem e o futuro ameaçador, o presente transformou-se numa dimensão de simultaneidades que se expandem", afirma o autor (GUMBRECHT, 2015, p.16). São tantas as opções para "preencher o tempo", que nada satisfaz; são tantas as informações, que não se consegue pensar. Cansaço, desorientação e angústia no cotidiano repetitivo do sanatório de Berghof, onde a cura dos males não chega. Como resume Thiago Abrahão, só há ali o "agora que parou” da existência doentia (2020, p. 9).

O personagem que faz do passado um projeto explícito de futuro é o ex-jesuíta Leo Naphta. Os sobrenomes possuem um caráter simbólico, pois se Lodovico Settembrini remete ao mês de início do outono - no hemisfério norte, claro - esse personagem manifesta o crepúsculo do projeto humanista das Luzes. Já o sobrenome Naphta indica a concepção conservadora e autoritária da sociedade, com o incômodo cheiro de naftalina. Há diversos embates entre ambos na obra, que não caberia resenhar aqui, sob a observação deleitosa do jovem Hans Castorp, o engenheiro que nada constrói, disputado eixo da narrativa romanesca9 . O mais interessante é que, após certo tempo, os dois personagens representativos, que tanto se opõem em questões político-sociais, vão habitar juntos fora do sanatório. A aproximação faz pensar que tais pseudo-soluções para os grandes problemas humanos talvez não sejam tão opostas assim e que a crescente polarização trazia cada vez mais perigos à convivência em sociedade. De qualquer modo, a abordagem dada pelo narrador aos discursos transpira a demagogia de ambos.

O fato que solidificou essa compreensão nas obras de Walter Benjamin foi a aliança entre comunistas e fascistas. $\mathrm{O}$ incomodo com a crescente aproximação do que deveria estar

\footnotetext{
${ }^{9}$ Curiosamente, Claude Levi-strauss escolhe a figura ideal do engenheiro para contrapor ao artesão (o bricoleur), produtor da magia, que opera sobre "uma coleção de resíduos de obras humanas", imagem de ressonâncias benjaminianas. $O$ engenheiro "sempre procura abrir uma passagem e situar-se além, ao passo que o bricoleur, de bom ou mau-grado, permanece aquém, o que é uma outra forma de dizer que o primeiro opera através de conceitos e o segundo através de signos" (1989, p.35). Não sendo engenheiros, coloca-se aqui, de outra maneira, a necessária tarefa de decifrar artesanalmente os signos da história de nosso tempo.
} 
em intenso combate, reunindo estranhamente o pior do capitalismo com o pior do comunismo, já advinha de alguns anos, comenta o biógrafo Bernd Witte. Os textos do final do final da década de trinta incorporaram, então, a "impotência desesperada a respeito da traição dos ideais revolucionários nos quais ele depositou as suas esperanças, também sua epistemologia" (2017, p. 132). Restou o "salto de fé" no tempo messiânico ${ }^{10}$, tão presente nas Teses, ou a figura do flâneur, com o desejo de explorar a porosidade das Passagens (BENJAMIN, 2018).

A visão do horizonte no cume da Montanha Mágica foi se estreitando, tanto quanto o visto dos montes de Portbou, onde o pensador judeu perdeu a própria vida. No penúltimo capítulo do romance de Mann, acontece a discussão final entre Settembrini e Naphta, acerca do tema fundamental da possível justiça entre os homens. Foi tão tensa que o ex-jesuíta termina com o desafio ao duelo mortal. Esse era um costume violento cultivado pelas famílias de estirpe, pertencia aos códigos de honra da nobreza militarizada do // Reich, porém no início do século XX já estava superado pela ascensão dos costumes burgueses, indica Nobert Elias (1997, p.69). A cena, descrita com toques irônicos, teve de ser mediada por Castorp, escolhido a contragosto como árbitro do fatídico embate. Caminharam armados em direção um ao outro, todavia Settembrini, ao terceiro passo, atirou com a pistola para o alto. O "humanista" não consegue matar seu oponente. Já Naphta, extremamente irritado com aquele gesto de desonra, volta a arma contra sua própria cabeça e atira (MANN, 2009, p. 589). O suicídio simbólico do conservadorismo elitista e autoritário é inserido na narrativa como um alerta, ou a consequência lógica, da violência que multiplica. O humanismo estava adoentado, mas sobreviveu ${ }^{11}$.

\section{A sociedade meio-pulmão}

Além de ser considerada uma obra sobre a experiência do tempo, $A$ Montanha Mágica tem sido interpretada enquanto romance de formação (Bildungsroman), como

\footnotetext{
${ }^{10}$ Como se sabe, essa é uma expressão do pensador dinamarquês Soren Kierkegaard. A aproximação dele com o pensamento benjaminiano, conquanto que de modo "indireto", foi feita por Bartholomew Ryan (2014). Na Tese 14 do conceito de história, o pensador alemão insere-o "sob o livre céu da história" enquanto um "salto dialético da Revolução" (BENJAMIN, 1994, p. 230).

${ }^{11} \mathrm{Em}$ 1930, bem depois da publicação do romance em tela, Thomas Mann fez um discurso de impacto em Berlim intitulado "O apelo à Razão", onde alertava sobre os perigos da vitória eleitoral do Partido Nazista. Mais tarde, circulou pela Europa e Estados Unidos defendendo sua posição anti-bélica e crítica ao totalitarismo. A atitude de indiferença dos intelectuais era um ponto constantemente denunciado em seus pronunciamentos, postura assumida publicamente após a I Guerra Mundial, nota Lukács (1964, p. 33).
} 
afirmou Pedro Caldas (2014). O personagem central é tratado narrativamente como um aprendiz, às vezes do amor, às vezes da ciência, às vezes dos valores patrióticos. Contudo, há sempre um quê de ironia nas posturas assumidas por ele, fazendo o autor uma crítica perene à atitude burguesa, segundo a leitura de Lukács (1964, p. 15), ou uma paródia dela, nos termos de Caldas (2014).

Podemos também aplicar essa interpretação ao próprio cenário do romance, ou seja, o sanatório em Davos. Ele não era exatamente um lugar para a cura, sendo bem melhor caracterizado como seu oposto, o de revelação da doença. O "ar rarefeito e seco das alturas" somente contribuía para identificá-la (MANN, 2009, p.154). O seu diretor, Dr. Behrens, é descrito como "um velho cínico" (MANN, 2009, p.10), sendo chamado por toda a obra de Conselheiro Áulico, o que remete tanto à corte principesca ali reunida, quanto ao aspecto pedagógico do lugar (MANN, 2009, p. 128). O outro médico, Dr. Krokowski, é marcado pelo pensamento sórdido (MANN, 2009, p. 55). Uma conferência que pronunciou considerava, por sinal, "o amor como fator patogênico"! (MANN, 2009, p. 101). Enfim, qual era a verdadeira doença ali? Após realizar "profundas investigações", Castorp descobriria que a falta de ar o constitui o sintoma, porém "a enfermidade é a forma licenciosa da vida". Eis "o pecado original" da origem dos seres vivos (MANN, 2009, p. 240) ${ }^{12}$.

Lá em cima estava "o mundo dos grã-finos" (MANN, 2009, p. 148), já "a seriedade existe somente na vida lá de baixo" (MANN, 2009, p. 45). Os da planície ignoravam como realmente se devia viver (MANN, 2009, p. 349). Em cima da montanha é que se "vive a liberdade" (MANN, 2009, p. 322). O pecado original cria esse mundo frívolo e licencioso da burguesia, das altas e ricas classes, contudo não existiria possibilidade de redimi-lo no capitalismo, conforme pensa Benjamin.

Em sua juventude, o pensador alemão fez algumas notas apontando o caráter pseudo-religioso do regima capitalista. Nesse opúsculo, afirmava sua preocupação com "uma doença do espírito" tornada global pelo sistema gestado pela burguesia (BENJAMIN, 2013, p. 33). Além disso, os fieis que celebravam a crença capitalista haviam criado "o primeiro caso de culto não expiatório, mas culpabilizador" (2013, p. 29). A montanha do Sanatório

\footnotetext{
${ }^{12}$ Antes dele, Settembrini já havia considerado a doença predominante do sanatório como a "forma de licenciosidade". Nesse diálogo, Hans Castorp ainda resiste e pensa que seria melhor caracterizá-la como uma consequência da vida licenciosa (MANN, 2009, p. 187).
} 
Internacional pode simbolizar, então, a "magia" de conviver com essa culpa, essa doença, ou ignorá-la se possível, por meio de suas festas, exibicionismos e rituais de comensalidade. Pior é que esse processo de adoecimento coletivo seria crescente, prevê o autor, "até que seja alcançado o estado de desespero universal” (2013, p. 31). Conjuntamente com a amputação da existência, o pecado original do acúmulo licencioso de capital "rende juros para o inferno do inconsciente" (2013, p. 32).

A perspectiva trágica indicada parece bastante atual. Não somente o espírito - a cultura para ser mais amplo, retomando o sentido pleno do termo alemão Geist - está doente: adoece o planeta como um todo ${ }^{13}$. A pandemia de COVID - 19 já encontrou a sociedade nessa espiral ascendente de desesperança, com a consciência de que o progresso social tornara-se impossível e as grandes expectativas ficaram depositadas em uma mísera vacina. O "estado de exceção", denunciava Benjamin na Tese 8, foi transformada em regra geral (1994, p. 226).

Destarte, a "sociedade meio-pulmão" não é apenas uma entidade do Sanatório em Davos (MANN, 2009, p. 44), mas uma metáfora da nossa organização social, dessa sensação de asfixia incrustrada em sua espinha dorsal. Franco Berardi identificou tal "falta de ar" ao aproximar a modernidade tardia do drama vivido na época barroca, quando

o artificio substituiu a natureza, a loucura tomou o lugar da razão e a aparência se sobrepôs ao ser. Perdida no labirinto das cidades, na batalha incessante pela sobrevivência e pela acumulação, a razão se transformou em astúcia, e a medida foi substituída pela força (BERRARDI, 2020, p. 116).

A face hipocrática da história está diagnosticada, mas a profilaxia da crise/doença ${ }^{14}$ demora a surgir no horizonte. No tribunal da história hegeliano, a Razão deveria triunfar, porém a crença nesse progresso já faleceu. Agora, o tempo da asfixia pandêmica aponta com insatisfatez para seu cadáver.

\section{O anjo na montanha}

Isso porque o capitalismo analisado racionalmente constitui, em sua essência, "um sistema absurdo" (BOLTANSKI, L. e CHIAPELLO, E., 2009, p. 39). Não há “novo espirito" -

\footnotetext{
${ }^{13}$ Guy Debord denunciava nos anos setenta, em texto intitulado $O$ planeta doente, que o capitalismo não deveria ser considerado somente um modo de organizar a economia, mas um sistema permanente de expropriação tanto da saúde dos seus próprios produtores quanto da integridade do meio-ambiente. Prevê ainda que decisões terríveis teriam de ser tomadas em um futuro próximo, entre a democratização geral ou o governo total (DEBORD, 2004).

${ }^{14}$ Relembramos que o termo crise, tão utilizado na economia-política, tem origem médica, remetendo ao agravamento do estado doentio do ser.
} 
retomando aqui o weberiano título dessa obra - que reanime o corpo social em desfiguração. A dessocialização ganhou a forma imperativa de um fato social verdadeiramente durkheiniano.

A aproximação semântica entre progresso e barbárie, intentada por Benjamin com tanto vigor por meio do conceito de história, foi realizada no decorrer do próprio tempo histórico. E isso tem sido demonstrado por via somática. Os que morrem jamais repousarão em paz "se o inimigo vencer", escreveu o pensador, pois o tempo messiânico chega como salvação e "como vencedor do Anticristo" (BENJAMIN, 1994, p. 224).

Adentra-se na difícil temática da categoria messiânica, considerada geralmente como o que lhe restava na fuga desesperada do aprisionamento. Essa interpretação desfaz de todo o potencial de sua noção, como apontamos em trabalho anterior (QUADROS, 2020). Não se trata do postular o além, mas da fusão entre transcendência e imanência numa única temporalidade. Isso é indicado pelo instigante e famoso personagem do anjo da História, descrito na Tese 9:

Seu rosto está dirigido para o passado. Onde nós vemos uma cadeia de acontecimentos, ele vê uma catástrofe única, que acumula incansavelmente ruína sobre ruína e as dispersa a nossos pés. Ele gostaria de deter-se para acordar os mortos e juntar os fragmentos. Mas uma tempestade sopra do paraíso e prende-se em suas asas com tanta força que ele não pode fechálas. Essa tempestade o impele irresistivelmente para o futuro, ao qual ele vira as costas, enquanto o amontoado de ruínas cresce até o céu (1994, p. 226)

$\mathrm{O}$ anjo benjaminiano enxerga os mortos, primeiro passo para a disponibilidade que abre ao engajamento histórico. Entretanto, é incapaz de agir, para conhecer de modo efetivo, já que seu corpo angelical é castrado. O desejo e a impotência se contrapõem à clareza do juízo crítico que consegue, pelo menos, identificar as ruínas ${ }^{15}$. A "catástrofe única" incomoda, mas não fornece o poder necessário para romper com a "cadeia de acontecimentos" e para "acordar os mortos", como ocorre na conhecida visão do profeta bíblico Ezequiel (37, 1-14).

Despertar os mortos seria interromper o tempo contínuo da involução humana; parar com a cronologia da repetição. "O giro copernicano de Benjamin na concepção temporal se

\footnotetext{
${ }^{15}$ Talvez a interpretação feita esteja marcada pelo filme Asas do desejo, de Win Wenders, onde para quebrar com a impotência de amar realmente e experimentar a história, os personagens angelicais têm de se tornarem anjos caídos. Alexandre F. Vaz expõe a clara aproximação "anacrônica", como diz, entre o anjo descrito por Benjamin e os dessa película, abordando-a como essencialmente "um filme sobre o tempo" (2019, p. 132), o que abriu a possibilidade de aproximá-lo também do romance de Thomas Mann aqui enfocado.
} 
substancia na categoria interrupção, que opõe-se frontalmente à concepção linear de tempo", escreveu Reys Mate (1993, p. 281). O oposto do tempo estaria na dimensão da eternidade. O papel dos anjos na mitologia judaica é justamente fazer a mediação entre o paraíso divino e a laboriosa vida histórica dos mortais.

O tempo messiânico não é um "fora do tempo", mas, na expressão bíblica, a plenitude dos tempos (um kairós oposto ao chronos, em grego) ${ }^{16}$. Essa condensação de temporalidades desafia-nos a não desistir de conhecer de modo global, relacional, entrecruzado e múltiplo, os processos de subjetivação, avaliando com sympathia ${ }^{17}$ o esforço militante de experimentar um pouco de "céu" e fugir dos "infernos" cotidianos. Simultaneamente observar com profunda atenção - significado original de theoria na língua grega - os processos de dessubjetivação que acarretam na irresponsabilidade social diante dos males da história.

A Montanha Mágica é, segundo Ricoeur, uma fábula moderna acerca do tempo, interposto em tensão permanente com a eternidade (1984, p. 193). A mediação entre os que "vivem no alto" e "aqueles de baixo" está ausente na obra. Faltam-Ihe anjos. Não só para conhecer e articular os espaços, mas para abrir os íngremes caminhos da ação política.

"A política ostenta o primado sobre a história", escreveu Benjamin (cf. nota 6). O pressuposto do mundo político é a alteridade, ou, como ensinava sua amiga Hannah Arendt, "a política baseia-se na pluralidade dos homens; [...] trata da convivência entre diferentes" $(2002$, p. 7). Nesse sentido, podemos perceber como os processos correntes de despolitização e de deshistoricização estão a confluir.

O ideal de viver em comum - na Polis - não deveria ser renegado, em que pese o medo do outro inserido nos vínculos sociais deste novo tempo do mundo. Já passamos da

\footnotetext{
16 Giorgio Agamben, tradutor de Benjamin, retrata o kairós como "um tempo que não é algo de objetivo e subtraído ao nosso controle, mas brota da ação e da decisão do homem. [...] O tempo infinito e quantificado - o chronos, acrescentamos - é assim repentinamente delimitado e presentificado: o kairós concentra em si os vários tempos..." (2005, p. 123-124).

${ }^{17}$ Importante destacar que isso é o oposto da empatia necessária ao conhecimento histórico, segundo postulava o historicismo. Como esclarece Reys Mate, "a empatia é, com efeito, a ponte que tende o passado para o presente, para que este reforce aquele. [...] A empatia é um engenhoso invento com o qual se beneficiam os vencedores de ontem e os dominadores de hoje. Se a sobredita possibilidade de conhecer o passado por meio da empatia ocorrer, os triunfadores de antanho poderão descansar tranquilos, pois graças a seus herdeiros seguem ganhando as batalhas, suas causas prosseguem vivas e eles gozando de boa saúde" (1993, p. 276). Na origem etimológica grega, syn significa junto, próximo e pathos, situação, sentimento, sofrimento, doença.
} 
"sociedade de risco", estudada por Ulrich Beck (2011), para a sociedade do medo ${ }^{18}$. Além de ferir a viabilidade salutar da convivência, isso altera radicalmente nossa sensibilidade com $o$ sopro que provém do futuro.

A ficção angelical benjaminiana evocava justamente a interpenetração dos tempos, a dinâmica da historicidade que assume passados para a edificação do novo. Já o infeliz engenheiro Hans Castorp, quando retornou à planície, faleceu sem qualquer utilidade, atolado no barro frio, dentre as botas dos soldados. O narrador nos deixa em suspenso a questão póstuma: "Será que também da festa universal da morte, da perniciosa febre que ao nosso redor inflama o céu desta noite chuvosa, surgirá um dia o amor?" (MANN, 2009, p. 598).

\section{Um copo vazio, mas cheio de ar}

Retornemos ao topos da asfixia contemporânea. Na época da ditadura civil-militar brasileira, as canções de Chico Buarque tinham enorme dificuldade para serem aprovadas na censura oficialmente instituída. Então, solicitou aos amigos algumas composições, para que pudesse gravá-las. Gilberto Gil, após apreciar um copo de vinho, observou que o objeto vazio estava cheio de ar, e fez a canção inserida como epígrafe desse artigo. ${ }^{19}$

Sua letra vincula insistentemente o ato de lembrar com a percepção da presença do ar. Os dispositivos de controle e de repressão podem até atingir os espaços microfísicos do poder, mas não conseguem impedir o movimento, não param o sopro do vento. $\mathrm{O}$ ar está sempre preenchendo o "espaço vazio", envolvendo o "rosto sombrio" e os corpos mutilados pela dor. Se a precariedade típica do novo tempo do mundo adoece as almas, o poeta deseja com vigor "a magia da verdade inteira, todo poderoso amor".

\footnotetext{
${ }^{18} \mathrm{O}$ estudo de Beck, produzido na década de oitenta, trata com rigor a centralidade social do risco, a exemplo do desastre ambiental ou da hecatombe nuclear, típico das décadas da Guerra Fria. No início do século XXI, isso muda para a difusão policêntrica e intensiva do medo, seja do outro, seja de si, da sociedade ou, até, do medo de ter medo. Tal mudança, sugerimos, é correlata a da sociedade disciplinar para a sociedade do controle (HARDT, M e NEGRI, A., 2001, p. 42).

${ }^{19}$ A situação que gerou a composição foi contada pelo próprio Gil: $A$ história da composição de Copo Vazio (https://www.youtube.com/watch?v=GFnRjdSA 6k, consultada em 22/02/2021). A letra da canção diz: "É sempre bom lembrar/ Que um copo vazio/ Está cheio de ar // É sempre bom lembrar/ Que o ar sombrio de um rosto/ Está cheio de um ar vazio/ Vazio daquilo que no ar do copo/ Ocupa um lugar// É sempre bom lembrar/ Guardar de cor/ Que o ar vazio de um rosto sombrio/ Está cheio de dor/ / Que o ar no copo ocupa o lugar do vinho/ Que o vinho busca ocupar o lugar da dor/ Que a dor ocupa metade da verdade/ A verdadeira natureza interior// Uma metade cheia/ Uma metade vazia/ Uma metade tristeza/ Uma metade alegria// A magia da verdade inteira/ Todo poderoso amor".
} 
O verso repetido na canção reúne, de maneira mágica, o que fora separado no processo tecnocientífico capitalista: verdade com amor, virtude com compaixão, epistemologia com ética, passado com futuro, até, viver com morrer. Desse modo, respirar transforma-se em conspirar por novos ares.

Subir a montanha - simbolicamente, topograficamente ou existencialmente - não é se conformar, nem tornar-se alienado dos demais seres. A crítica literária de Mann pode indicar uma nova forma de descobrir horizontes, de ver acima das densas nuvens cinzentas. Os anjos na mitologia judaica, a exemplo do descrito por Benjamin a velar pela história humana, assim o fazem de modo intermitente, criando vínculos entre a terra e o céu.

A lição do escalar poderia, ainda, ser invertida, tornando-se um momento conjuntivo para suspender o céu. A promessa celeste sustentada pela crença religiosa que sustenta o capitalismo, afinal, é opressora. Assim nos ensina o sábio indígena Ailton Krenak:

Cantar, dançar e viver a experiência mágica de suspender o céu é comum em muitas tradições. Suspender o céu é ampliar o nosso horizonte; não o horizonte prospectivo, mas um existencial. É enriquecer as nossas subjetividades, que é a matéria que este tempo que nós vivemos quer consumir. Se existe uma ânsia por consumir a natureza, existe também uma por consumir subjetividades - as nossas subjetividades. Então vamos vivêlas com a liberdade que formos capazes de inventar... (KRENAK, 2019, p. 29).

O nomadismo incessante dos povos tradicionais mostra um caminho para trazer o amanhã, onde se respira a plenos pulmões.

\section{REFERÊNCIAS BIBLIOGRÁFICAS}

ABRAHÃO, Thiago H. de Camargo. A liberdade em A Montanha Mágica. Pandemonium Germanicum, 23, 40, mai 2020, p. 1-19.

AGAMBEN, Giorgio. Infância e história: destruição da experiência e origem da história. Belo Horizonte: Editora UFMG, 2005.

APATA, Gabriel O. "I can't breathe": the suffocating nature of racism. Theory, Culture \& Society, v. 37, 7-8, 2020, p. 241-254.

ARANTES, Paulo. O novo tempo do mundo. São Paulo: Boitempo, 2014.

ARENDT, Hannah. O que é política? 3. ed. Rio de Janeiro: Bertrand Brasil, 2002.

BECK, Ulrich. Sociedade de risco - rumo a outra modernidade. 2. ed. São Paulo: Editora 34, 2011.

BENJAMIN, Walter. Origem do drama barroco alemão. São Paulo: Brasiliense, 1984. 
BENJAMIN, Walter. Sobre o conceito da história. 5. ed. In: BENJAMIN, W. Magia e técnica, arte e política. São Paulo: Editora Brasiliense, 1994, p. 222-232.

BENJAMIN, Walter. Experiência e pobreza. 5. ed. In: BENJAMIN, W. Magia e técnica, arte e política. São Paulo: Editora Brasiliense, 1994, p. 109-114.

BENJAMIN, Walter. O capitalismo como religião. São Paulo: Boitempo, 2013.

BENJAMIN, Walter. Passagens. 2a ed. Belo Horizonte: Editora da UFMG, 2018.

BERARDI, Franco. Asfixia: capitalismo financeiro e insurreição da linguagem. São Paulo: UBU Editora, 2020.

BOLTANSKI, Luc e CHIAPELLO, Eve. O novo espírito do capitalismo. São Paulo: Martins Fontes, 2009.

CALDAS, Pedro S. Pereira. O murmurante evocador do passado: a montanha mágica e o romance de formação. Revista História da Historiografia, 16, dez. 2014, p. 107-120.

DEBORD, Guy. La planète malade. Paris: Gallimard, 2004.

DIDI-HUBERMAN, Georges. Diante do tempo - História da arte e anacronismo das imagens. Belo Horizonte: Editora UFMG, 2015.

DORAN, Robert. Choosing the past: Hayden White and the Philosophy of History. In: DORAN, R. (ed.). Philosophy of History after Hayden White. New York: Bloomsbury Publishing, 2013, p. 1-34.

DUMOULIN, O. Anacronismo. In: BURGUIÈRE, André (org.). Dicionário das Ciências Históricas. Rio de Janeiro: Imago Editora, 1993, p. 47-48.

ELIAS, Nobert. Os alemães: a luta pelo poder e a evolução do habitus nos séculos XIX e XX. Rio de Janeiro: Jorge Zahar, 1997.

HARTOG, François. Evidência da História: o que os historiadores veem. Belo Horizonte: Autêntica Editora, 2011.

HARDT, Michael e NEGRI, Antonio. Império. Rio de Janeiro: Record, 2001.

HARDT, Michael e NEGRI, Antonio. Multidão: guerra e democracia na era do império. 2. ed. Rio de Janeiro: Record, 2012.

GINZBURG, Carlo. Mitos, emblemas, sinais: morfologia e história. São Paulo: Companhia das Letras, 1989.

KERN, Stephen. The culture of Time and Space (1880-1918). 2. ed. Cambridge: Harvard University Press, 2003.

KRENAK, Ailton. Ideias para adiar o fim do mundo. São Paulo: Companhia das Letras, 2019. 
KOSELLECK, Reinhart. Crítica e crise: uma contribuição à patogênese do mundo burguês. Rio de Janeiro: Contraponto Editora, 1999.

LOWY, Michael. Walter Benjamin: aviso de incêndio. São Paulo: Boitempo editorial, 2005.

LÖWITH, Karl. O sentido da história. Lisboa: Edições 70, 1991.

LUKÁCS, Georg. Essays on Thomas Mann. London: Merlin Press, 1964.

MANN, Thomas. A Montanha Mágica. Lisboa: Dom Quixote, 2009.

MANN, Thomas. A montanha mágica, de Thomas Mann. Revista Perspectivas, São Paulo, 19, 1996, p. 131-142.

MATE, Reys. La historia como interrupción del tempo. In: MATE, Reys (ed.). Filosofia de la historia. Valladolid: Simancas Ediciones, 1993, p. 271-287.

QUADROS, Eduardo G. Voltar a Benjamin, novamente. In: PASSOS, A. A.; BENTO, L. C.; GODOI, R. T (orgs.). Historiografia crítica: ensaios de analítica e hermenêutica da História. Vitória, ES: Editora Milfontes, 2020, p. 143-160.

RICOEUR, Paul. La configuration du temps dans le récit de fiction (temps et récit - tome II). Paris: Éditions du Seuil, 1984.

RYAN, Bartholomew. Kierkegaard's indirect politics - Interludes with Lukács, Schmitt, Benjamin and Adorno. New York: Rodolpi Press, 2014.

$\mathrm{SCHWAB}, \mathrm{Klaus.}$ A better economy is possible. But We need to reimagine capitalism to do it. Time USA, 22/10/2020. Disponível em: https://time.com/collection/greatreset/5900748/klaus-schwab-capitalism/, consultada em 07/02/2021.

VAZ, Alexandre Fernandez. Elogio ao anacronismo: afetos, memórias, experiências em Asas do Desejo, de Win Wenders. Educação em Revista, 35, 73, jan.-fev. de 2019, p. 117-134.

VIRNO, Paolo. Virtuosismo e revolução: a ideia de mundo entre a experiência sensível e a esfera pública. Rio de Janeiro: Civilização Brasileira, 2008.

WITTE, Bernd. Walter Benjamin - uma biografia. Belo Horizonte: Autêntica Editora, 2017. 